\title{
Antecedents of Green Consumer Behavior the Mediating Role of Brand Image in the Cosmetic Industry
}

\author{
Sikandar Ali Qalati ${ }^{1}$, Wenyuan Li $^{1}$, Sajid Hussain Mirani², Jan Muhammad
}

Sohu ${ }^{1}$, Rana Yassir Hussain ${ }^{1}$, Naveed Ahmed ${ }^{1}$

\begin{abstract}
In today's world, the demand for cosmetic products is increasing at a faster rate than before, and companies have begun to manufacture cosmetic products to cater to the needs of local and international users. This paper aims to explore the relationship between celebrity endorsement, promotional activities, packaging, brand image, and green consumer buying behavior in the cosmetic industry of Pakistan. It also examines the mediating role of the brand image. The paper used a closed-ended questionnaire to gather data from randomly selected respondents. Partial least square structural equation modeling (PLS-SEM) using ADANCO 2.0.1, used for the path analysis of 190 responses from four universities of Pakistan. The findings revealed a direct positive relationship between celebrity endorsement, promotional activities, packaging of a product, and brand image with the green consumer buying behavior. Partial mediation was found between celebrity endorsement and green consumer buying behavior. This study has implications for practitioners and researchers interested in investing in green consumption behavior.
\end{abstract}

Keywords: celebrity endorsement, promotional activities, packaging of products, brand image, cosmetic industry, green consumer buying behavior.

JEL Code: M31, O13, O47, Q01, Q50

\section{Introduction}

Green Consumer buying behavior refers to the "concerns for the environment, and about population, willingness to recycle, and to pay more for environmentally friendly products form this behavior." (Kaufmann \& Panni, 2017). The increasing trend has been shown towards the consumption of green products, as it enables individuals to participate in environmental sustainability (Sun, Liu, \& Zhao, 2019). Globally, celebrity endorsement in Asian countries is higher than the United States and European countries.

\footnotetext{
${ }^{1}$ School of Management, Jiangsu University, 301 Xuefu Road, Jinkou District, Zhenjiang, Jiangsu, P.R. China

${ }^{2}$ Department of Public Administration, Shah Abdul Latif University, Khairpur Corresponding Author: jansohu7@gmail.com
} 
In China and South Korea, it ranged from 25 to 61 percentage, while just 15 percent in European countries (Chekima, Wafa, \& Sulong, 2018).

Intrinsic as well as extrinsic motivation play a vital role in the green behavior of consumers as consumer green buying behavior is affected by consumer motivation. In contrast, intrinsically, females are more motivated to show green buying behavior compared to males (Gilal et al., 2019). Nowadays, organizations are motivated to find efficient communications strategies and design innovative marketing activities that energize consumers to buy environmentally friendly products and adopt green consumption buying behavior (Amatulli et al., 2019). Consumers tend to show more green behavior when they use green products as green products satisfy their environmental concerns (Zhang, Xiao, \& Zhou, 2019). However, people's concerns extended from the food industry to the cosmetic industry. Consumers have shown increasing interest in sustainable packaging, natural ingredients, and other green factors of cosmetics. Therefore, the cosmetic industry needs to be investigated; also, green cosmetics is considered an emerging trend in the beauty industry (Lin et al., 2018).

Nowadays, cosmetic products are considered as essential as other daily products, especially women, are more likely to attract. When companies use harsh chemicals in their products, not only consumers but also the environment faces an adverse effect (Amberg \& Fogarassy, 2019). The cosmetic industry is one of those industries in Pakistan, which uses a massive amount of chemicals and artificial materials that cause consumers and the environment to suffer a lot (Jamil, Ali, \& Iqbal, 2017). Nevertheless, with time, consumers are getting aware of the situations and adverse effects. So the demand for organic or green cosmetic items is increasing, and customers prefer green cosmetic products to accomplish consumption sustainability (Ali, 2017). Indeed, green products and green buying behavior have taken all the lame light because of the environmental degradation where the consumption is also increasing (Taufique \& Vaithianathan, 2018). The resultant of which cosmetics companies have started considering different factors that affect their sales revenue and consumers (Wang \& Uslay, 2018).

Several factors influence the buying behavior of customers, such as packaging, promotional activities, brand image. Moreover, endorsements are done by the favorite celebrities of the consumers, also influence their buying behavior and help to promote products. There are many other factors, too, which affect consumer buying behavior in a cosmetic product, but this study focuses on four factors only which are; celebrity endorsement, promotions, packaging and brand image and its relationship on women's behavior to buy such products.

Byrne, Whitehead, and Breen (2003) defined celebrity endorsement as "any individual who enjoys public recognition and who uses this recognition on behalf of a consumer good by appearing with it in an advertisement. It is a popular form of advertising

Sukkur IBA Journal of Management and Business - SIJMB | Vol 7 No. 1 January - June 2020 @) Sukkur IBA University 
Sikandar Ali et al Antecedents of Green Consumer Behavior the Mediating Role of Brand Image in the Cosmetic

through which companies promote their products or services and create awareness (Chekima et al., 2018).

Moreover, marketers hope that the fame and status of endorses would create a distinct and positive image in the minds of customers; also, it will attract customers to buy a product. According to Adam and Hussain (2017), celebrities positively impact the green Consumer buying behavior and transfer the meaning to the product. Consumers readily accept the endorsed products and make them feel classy and consider it as a symbol of status. This process is mainly used by fashion or beauty brands.

Promotional activities refer to those set of activities that communicate the product, service, or brand to the end-user (Shallu \& Gupta, 2013). The main idea is to aware of people and makes them buy a particular product in preference over the other brands. More profoundly, promotional activities not only include advertising but also used to attract customers to purchase and try the products (Mullin, 2018). Promotional activities are playing a vital role in changing the consumer's perception of a brand. Also, to attract and invite customers to purchase a product or service and even to switch to other brands (Khare, 2015).

Packaging refers to the overall designing, evaluating, and producing the container for a product to keep or store it against the damages and to attract the customers to a particular product. According to Salem (2018), it is one of the essential element through which companies communicate to the consumers by providing the necessary information on the packages and (Prakash \& Pathak, 2017), consider packaging as one of the essential tools to attract the green consumers, and also affects their purchase decision.

Brand image refers to an image a customer has in his mind regarding a brand. It plays a vital role in boosting up any business or company performance, and it is now considered as an asset. It is developed with time by company quality service/product given to its customers and by customers' direct interaction and experience (Jin, Line, \& Ann, 2015). Chen et al. (2020), proposed that brand image should be focused and increased to improve green consumer buying behavior.

To explain these associations, the theory of planned behavior (TPB) has been used. After verifying the conceptual model, the theory of planned behavior has been associated with green consumer buying behavior and celebrity endorsement. Gilal et al. (2020) studied the CSR and brand passion among consumers for soft drink brand, findings concluded that consumer passion is directly affected by consumer perception of CSR and showed a positive impact on brand attachment, Which means that when consumers know that company is playing its role for the betterment of the environment, then they create an emotional attachment with the brand and prefer to buy its products or services. In the same way, this study also focuses on the consumer buying behavior and how celebrity endorsement influences their buying behavior towards the particular product in the cosmetic industry, as providing green cosmetic products referred by favorite personality create the sense of credibility and positive image of the company, which influence the consumer to buy green cosmetic products.

Sukkur IBA Journal of Management and Business - SIJMB | Vol 7 No. 1 January - June 2020 @ S Sukkur IBA University 
Sikandar Ali et al Antecedents of Green Consumer Behavior the Mediating Role of Brand Image in the Cosmetic

The objectives of the study are to investigate the effects of celebrity endorsement, promotional activities, packaging, and brand image on the green consumer buying behavior and mediating role of brand image in the cosmetic industry of Pakistan.

\section{Literature review}

\subsection{Celebrity endorsement and green consumer buying behavior}

Globally, celebrity endorsement in Asian countries is higher than in the United States and European countries (Chekima et al., 2018). In China and South Korea, it ranged from 25 to 61 percentage, while just 15 percent in European countries (Chekima et al., 2018). Today's era of celebrity endorsement shifted from traditional towards celebrity 2.0, where celebrity endorses the products via using Facebook profile and other emedia. It also faster the process of reach (Jin, 2018). This social, technological change was the most useful to reduce the adverse environmental effect and speed up the process to achieve sustainable consumption. The conceptual model has been developed based on the theory of planned behavior.

According to the theory of planned behavior; developed by Ajzen (1985), a person's attitude, along with subjective norms, and perceived behavioral control, shapes the behavioral intentions and, finally, behavior. Behavioral intentions shaped by attitude (attitude of celebrity choice) and subjective norms (luxurious brands) and behavioral control (Cuomo et al., 2019). In the cosmetic industry, consumer perception has a positive effect on purchase intension while consumer perception is positively affected by expertise (Skill, experience, and knowledge) and physical attractiveness(Adi, 2012).

The prior scholars confirmed that celebrities could influence green buying behavior (Kumar \& Tripathi, 2019). Industries are growing with time, along with that the sales of goods and services also shooting up, but when we see their impact on the environment, it is getting worse. So sustainable consumption is one of the ways to reduce it. The environmentally friendly products, which we also call green products, can help to accomplish sustainable use (de Medeiros \& Ribeiro, 2017). Therefore, we proposed the following hypothesis

H1: There is a significant relationship between celebrity endorsement and green consumer buying behavior.

\subsection{Promotional activities and green consumer buying behavior}

The promotion of green purchase and environmentally friendly practice is considered a significant medium to lessen the adverse effects on the environment and its sustainability. The promotional activities, especially change in prices, can influence green purchase behavior (Liobikienè, Grincevičienè, \& Bernatonienè, 2017). Promotional activities are one of the dominant factors in green marketing to impact green consumption. However, Codini, Miniero, and Bonera (2018), the study confirmed that promotional activities rather than prevention influence people towards green

Sukkur IBA Journal of Management and Business - SIJMB | Vol 7 No. 1 January - June 2020 C Sukkur IBA University 
Sikandar Ali et al Antecedents of Green Consumer Behavior the Mediating Role of Brand Image in the Cosmetic

buying behavior. Khare (2015), proposed that social organizations, government, and firms should establish green promotional activities that focus on environmental prevention, green identity, and social image of individuals linked with green buying behavior. Henceforth, we develop the following hypothesis

H2: There is a significant relationship between promotional activities and green consumer buying behavior.

\subsection{Packaging of products and green consumer buying behavior}

Nowadays, green packaging plays a vital role in the sustainability of environmental and consider as a solution for numerous environmental issues. There are increasing concerns related to environmental prevention among green consumers, which are forcing producers to develop environmentally friendly products (Mishra, Jain, \& Motiani, 2017). As most individuals aware of the influence of packaging on the atmosphere, they prefer to buy eco-friendly products due to environmental prevention, feeling of being responsible, and recycle. Orzan et al. (2018), the study confirmed that the eco-friendly packaging leads to green buying. More particularly, young consumers showed a positive attitude towards eco-friendly packaging and are willing to pay high prices for green products (Prakash \& Pathak, 2017). According to Ghosh (2016), in a competitive market environment, packaging plays a crucial role and is become a tool of differentiating the product. Moreover, it has significant impacts on consumer buying behavior (Simmonds \& Spence, 2017).

H3: There is a significant relationship between the packaging of products and green consumer buying behavior.

\subsection{Celebrity endorsement and brand image}

Celebrity endorsement is one of the common advertising strategies for developing a brand image (recall and recognition) (Chan, $\mathrm{Ng}$, \& Luk, 2013). Due to increasing competition and advertising clutter, marketers prefer celebrities to endorse marketing communication strategies to receive consumer attention, develop interest, increase desire, and motivate them towards the purchase action and also strengthen the bonding with firm bands (Ateke, Onwujiariri, \& Nnennanya, 2015). Ford (2018), proposition, organizations have realized the celebrity endorse can improve the brand image, brand awareness as well as advertisement credibility, liking, and buying behavior. Therefore, we proposed the following hypothesis;

H4: There is a significant relationship between celebrity endorsement and brand image.

\subsection{Relationships between brand image and green consumer buying behavior}

A body of literature on brand image and eco-friendly consumers has developed over the years. In general, consumers are influenced by social, personal, and psychological factors that impact their perception of a brand. Brand image is a powerful tool to influence more consumers and motivate them to buy green products (Suki, 2016).

Sukkur IBA Journal of Management and Business - SIJMB | Vol 7 No. 1 January - June 2020 @) Sukkur IBA University 
Sikandar Ali et al Antecedents of Green Consumer Behavior the Mediating Role of Brand Image in the Cosmetic

Indeed, the benefits of waste reduction and environmental prevention for several green products may resonate more efficiently with consumers. This behavior hopes to generate both a positive brand image and a higher rate of acceptance of green consumption (Royne et al., 2016). Consumers incline to observe more top quality and brand image of firms when it dues to offer eco-friendly products ( $\mathrm{Ng}$ et al., 2014). Durrani et al. (2015), studied the relationship between the impact of brand image on teenagers buying behavior in the context of Pakistan. Besides, Nagar and Rana (2015), found a significant association between brand image and green purchase intention. Hence, we proposed the following hypothesis;

H5: There is a meaningful relationship between brand image and green consumer buying behavior.

\subsection{Mediating role of brand image}

According to Gill and Dawra (2010), proposition brand image can mediate the relationship between the proposed construct. Tariq et al. (2017), confirmed the mediating role of brand image and found full mediation between the electronic word of mouth and purchase intention, and partial mediation between brand awareness and purchase intention. Moreover, the green brand attitude and positioning receive strong bonding with green consumer and green value-driven activities of the firms (Suki, 2016). Marketers believe that celebrity endorsement impacts advertising effectiveness, brand recognition, and also purchase decision and follow-through (Spry, Pappu, \& Cornwell, 2011). Likewise, Chan et al. (2013), found the mediating role of a brand image between celebrity endorsement and purchase intention. Moreover, the brand image also mediates the relationship between corporate social responsibility and purchase intention (Ramesh et al., 2019). Thus, we proposed the following hypothesis;

H6: Brand image has a mediation effect on celebrity endorsement and green consumer buying behavior. 


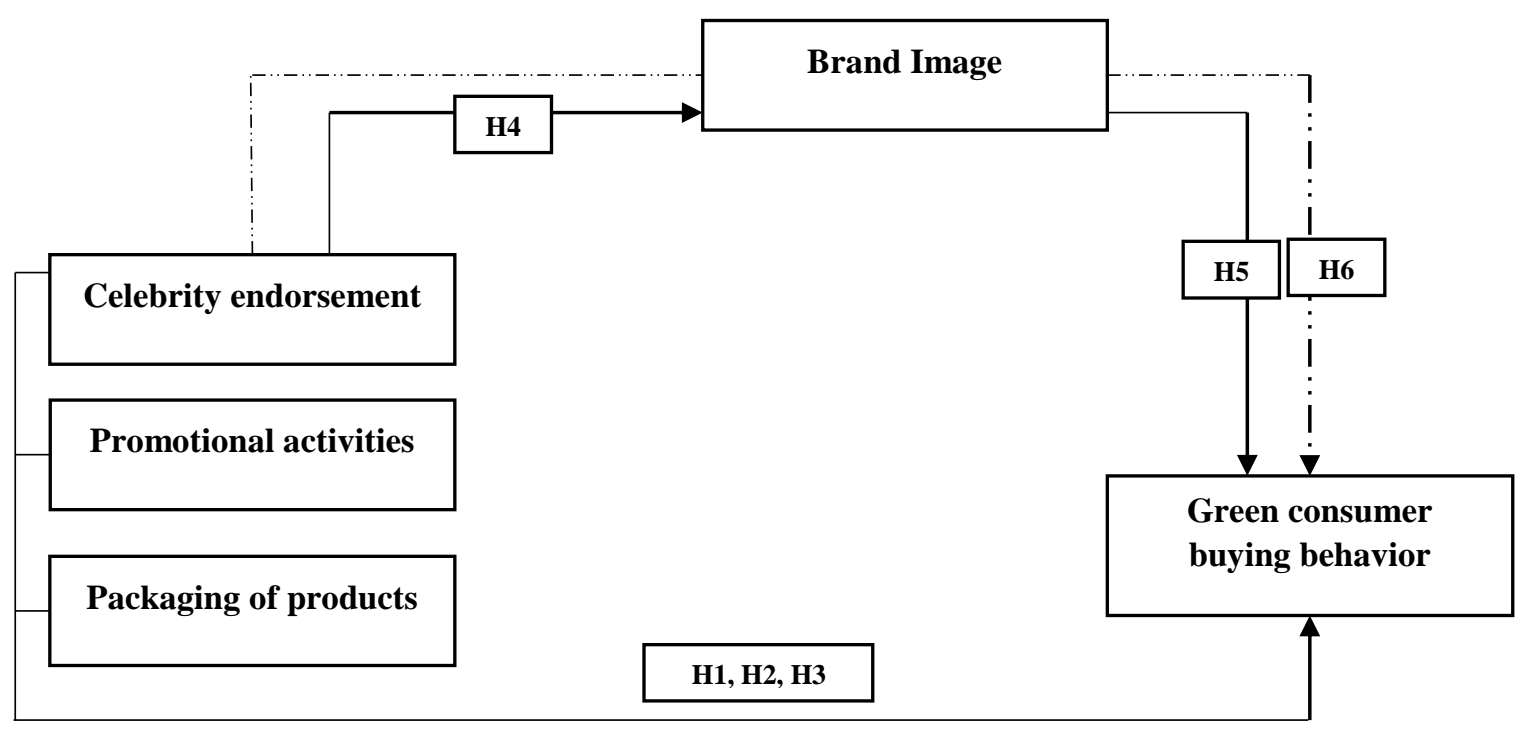

Figure 1. Conceptual Framework

\section{Methodology}

\subsection{Sampling and data collection}

This study used a quantitative method to collect data, as the field is becoming increasingly quantitative (Groeneveld et al., 2015). A technique of convenient random sampling used to select the respondent as it is considered one of a fast, simple, and less costly approach of collecting data (Salganik \& Heckathorn, 2004). The data source of the study is 'primary'; this data is collected directly from the respondents. The respondents are only females from different universities of Pakistan (SZABIST Islamabad, Shah Abdul Latif University Khairpur, UMT Lahore, and IQRA University) as they mostly use the cosmetics products (Singhal \& Malik, 2018). The respondents were assured that their participation is voluntary, confidential, and anonymous. At first, we informed participants about the purpose of the study, then we distributed a questionnaire among them with the permission of educators' and 20 minutes were allowed to fill the questionnaire. The reason behind the selection of female students includes, they are more inclined towards beauty products and have higher possessiveness towards environments (Yousaf et al., 2012). Also, because, according to Weiss (2012), a suggestion, the respondents of the study should possess similar characteristics. In the present study, 200 questionnaires were distributed, resulting in 190 valid responses, with a $95 \%$ response rate. 


\subsection{Measures of the study}

This study used five-point Likert scales (1= "strongly disagree"; 5= "strongly agree") to record participants' responses. The participants were informed through about content and the purpose of study through many convenient methods of the survey, which includes some personal interviews, emails, telephone calls, and online approaches. Data were collected with their consent, and participants were informed about research before the survey. Celebrity endorsement was measured using four items (e.g. you are likely to purchase celebrity-endorsed cosmetics) adapted from (Gauns et al., 2018). Promotion activities were assessed using four items (e.g. promotions are necessary to attract customers) borrowed from (Lin, 2015; Sohail, 2016). Packaging of products was evaluated using three items (e.g. packaging of the cosmetic products is important to me) adapted from (Silayoi \& Speece, 2004). The brand image was measured using four items (e.g. cosmetics Brand image affects your buying behavior) taken from (Ng et al., 2014). Green consumer buying behavior was assessed using four items (like the quality of cosmetic products makes you loyal to the brand) taken adapted from (Khare, 2015).

\subsection{Data analytical tool}

This study used ADANCO 2.0.1, partial least squares structural equation modeling (PLS-SEM) to build, execute and validate hypothesized model and the mediating effect of brand image (Henseler \& Dijkstra, 2018), given its widespread application in business management and related disciplines (Fassott, Henseler, \& Coelho, 2016), and it is considered fastest and newest fully developed and comprehensive system of variance (Henseler, 2018). In contrast, we used PLS-SEM over co-variance-based structural equation modeling (CB-SEM) because CB-SEM requires data to be normally distributed. Whiles PLS-SEM holds no assumption about distributions of data. Thus, the overall results of a statistical test are not contradicted by non-normal data (Goodhue, Lewis, \& Thompson, 2012), hence the use of PLS-SEM.

\section{Results Analysis}

\subsection{Descriptive information}

The sample of this study was only female. Table 1 illustrates that most of the respondents [173 (91.1\%)] were aged between 18 and 25 years and were undergraduate [122 (64.2\%)]. Thus, most decision-makers were young and well-educated. 14.2\% of intermediate students were those who are either preparing for admission tests or doing short courses. The majority of respondents' expenses were over 3000 (65.7\%). Regarding frequency, the majority of respondents frequently buying were 87 (45.8\%). Regarding the preferences, most of the respondents, 171 (90.0\%), reported imported products. 
Sikandar Ali et al Antecedents of Green Consumer Behavior the Mediating Role of Brand Image in the Cosmetic

Table 1: Descriptive Information

\begin{tabular}{|l|l|c|c|}
\hline Respondents & & Frequency & Percentage \\
\hline Age (years) & $18-25$ & 173 & 91.1 \\
\hline & $26-33$ & 15 & 7.9 \\
\hline & & & \\
\hline & $34-41$ & 2 & 1.1 \\
\hline Education & Over 41 & 0 & 0 \\
\hline & Intermediate & 27 & 14.2 \\
\hline & Undergraduate & 122 & 64.2 \\
\hline Expenditure in (Rs) & Master's & 41 & 21.6 \\
\hline & $>3000$ & 65 & 34.2 \\
\hline $\begin{array}{l}\text { Frequency of buying } \\
\text { cosmetic products }\end{array}$ & Rarely & 125 & 65.7 \\
\hline & Frequently & 69 & 36.3 \\
\hline & Very frequently & 29 & 45.8 \\
\hline & Don't shop & 5 & 2.6 \\
\hline $\begin{array}{l}\text { Preference for } \\
\text { products }\end{array}$ & Local & 19 & 10 \\
\hline & Imported & 171 & 90 \\
\hline & & & \\
\hline
\end{tabular}

\subsection{Model analysis}

Before conducting PLS-SEM tests, reliability, validity, and path-coefficient assumptions related to multicollinearity, normality, and bias were measured using the two-step approach proposed by (Barclay et al., 1995) to assess the measurement model and the structural model.

\subsubsection{Assessment of the measurement model}

According to Roldán and Sánchez-Franco (2012), a proposition to measure the model is required to assess the individual item reliability, internal consistency, content validity, convergent validity, and discriminant validity (see Table 2).

Individual item reliability was measured by outer loadings of items related to a particular dimension (Hair et al., 2012). Hair et al. (2016) recommended that factor loading should be between 0.40 and 0.70 , whereas (Hair Jr et al., 2017) proposed a 
Sikandar Ali et al Antecedents of Green Consumer Behavior the Mediating Role of Brand Image in the Cosmetic Industry

(pp. 19-39)

value of $\geq 0.7$ (Table 2). According to Nunnally (1978), Cronbach's alpha values should exceed 0.7: the threshold values of constructs in this study ranged from 0.881 to 0.959 .

Internal consistency reliability Bagozzi and Yi (1988) requires composite reliability (CR) to be $\geq 0.7$ : the coefficient values of $\mathrm{CR}$ in this study were between 0.838 to 0.960 .

Regarding convergent validity, Fornell and Larcker (1981) recommended that the average variance extracted (AVE) should be $\geq 0.5$. AVE values in this study were between 0.670 and 0.892 , confirming a satisfactory level of convergent validity.

Table 2: Measurement model

\begin{tabular}{|l|c|c|c|c|c|}
\hline & & & & & \\
\hline & Item code & Loading & CR & CA & AVE \\
\hline Celebrity endorsement & CE1 & 0.767 & 0.838 & 0.835 & 0.670 \\
\hline & CE2 & 0.837 & & & \\
\hline & CE3 & 0.867 & & & \\
\hline Promotional activities & CE4 & 0.800 & & & \\
\hline & PA1 & 0.941 & 0.960 & 0.959 & 0.892 \\
\hline & PA2 & 0.947 & & & \\
\hline & PA4 & 0.946 & & & \\
\hline Packaging of product & PoP1 & 0.944 & & & \\
\hline & PoP2 & 0.917 & 0.891 & 0.886 & 0.815 \\
\hline & PoP3 & 0.896 & & & \\
\hline Brand image & BI1 & 0.882 & 0.912 & 0.908 & 0.785 \\
\hline & BI2 & 0.879 & & & \\
\hline & BI3 & 0.892 & & & \\
\hline & BI4 & 0.889 & & & \\
\hline Green consumer & GCBB1 & 0.840 & 0.885 & 0.881 & 0.738 \\
\hline buying behavior & GCBB2 & 0.889 & & & \\
\hline & GCBB3 & 0.883 & & & \\
\hline & GCBB4 & 0.822 & & & \\
\hline
\end{tabular}

Note: $\mathrm{CE}=$ Celebrity endorsement, $\mathrm{PA}=$ Promotional activities, $\mathrm{PoP}=\mathrm{Packaging}$ of the product, $\mathrm{BI}=\mathrm{Brand}$ image, $\mathrm{GCBB}=\mathrm{Green}$ consumer buying behavior, $\mathrm{CR}=\mathrm{Composite}$ reliability, $\mathrm{CA}=\mathrm{Cronbach}$ 's Alpha, $\mathrm{AVE}=$ Average variance extracted

Source: Authors' processing from ADANCO (dvanced Analysis of Composites) 2.1 Version 
Sikandar Ali et al Antecedents of Green Consumer Behavior the Mediating Role of Brand Image in the Cosmetic Industry

(pp. 19-39)

Regarding discriminant validity, according to Fornell and Larcker (1981), the square root of the AVE for each construct should exceed the inter-correlations of the construct with other model constructs. Table 3 demonstrates the discriminant validity of the results.

It is worth noting that the values in the diagonal (in bold) of the Fornell- Lacker's table (see table 3) indicate AVE's of the measured constructs and must greater than 0.5. At the same time, each construct's AVE should be of higher value (coefficient) at both column and row position over other constructs.

Table 3. Discriminant Validity: Fornell-Larcker Criterion

\begin{tabular}{|l|c|c|c|c|c|}
\hline \multicolumn{1}{|c|}{ Construct } & 1 & 2 & 3 & 4 & 5 \\
\hline Green consumer buying behavior & 0.7383 & & & & \\
\hline Celebrity endorsement & 0.4483 & 0.6705 & & & \\
\hline Promotional activities & 0.3631 & 0.3584 & 0.8927 & & \\
\hline Packaging of products & 0.3995 & 0.4925 & 0.3182 & 0.8153 & \\
\hline Brand Image & 0.4409 & 0.3046 & 0.3186 & 0.1925 & 0.7852 \\
\hline
\end{tabular}

Note Squared correlations; AVE in the diagonal.

The Heterotrait-Monotrait ratio is used to assess factors discriminant validity. According to Voorhees et al. (2016), proposition it would be better if the value of constructs is below 0.85 (see table 4 ), 0.8142 become maximum value retained.

Table 4. Discriminant Validity: Heterotrait-Monotrait Ratio of Correlations (HTMT)

\begin{tabular}{|l|c|c|c|c|c|}
\hline \multicolumn{1}{|c|}{ Construct } & 1 & 2 & 3 & 4 & 5 \\
\hline Green consumer buying behavior & & & & & \\
\hline Celebrity endorsement & 0.7766 & & & & \\
\hline Promotional activities & 0.6536 & 0.6688 & & & \\
\hline Packaging of products & 0.7115 & 0.8142 & 0.6087 & & \\
\hline Brand Image & 0.7382 & 0.6318 & 0.6027 & 0.4838 & \\
\hline
\end{tabular}

Source: Authors' processing from ADANCO 2.1 Version

\subsubsection{Assessment of the structural model}

This study used PLS bootstrapping with 999 bootstraps and 190 cases to reflects the path coefficients and their significance (Henseler, Ringle, \& Sinkovics, 2009). Figure 2 displayed the comprehensive picture of assessments from the structural model. According to Wong (2013), the structural model should be deployed to evaluate the liner regression effects of the dependent variables on one another. A structural equation

Sukkur IBA Journal of Management and Business - SIJMB | Vol 7 No. 1 January - June 2020 C Sukkur IBA University 
Sikandar Ali et al Antecedents of Green Consumer Behavior the Mediating Role of Brand Image in the Cosmetic

model used path coefficient and indicator of the level of significance as well as the coefficient of determination.

According to Cohen (1998), $\mathrm{R}^{2}$ values of $0.60,0.33$, and 0.19 are, respectively, substantial, moderate, and weak. As shown in Table 5, the estimated $\mathrm{R}^{2}$ of the brand image showed the construct celebrity endorsement explains $30.46 \%$ of the variation in the brand image. Again, the $\mathrm{R}^{2}$ of green consumer buying behavior (0.6207) showed a $62.07 \%$ variation in the construct green consumer buying behavior is explained by the construct's celebrity endorsement, promotional activities, packaging of the product, and brand image.

The standard root means square residuals defines "quantifies how strongly the empirical correlation matrix differs from the model-implied correlation matrix" (Henseler, 2017). $\mathrm{Hu}$ and Bentler (1999), proposed 0.08 cut-off value, according to (Byrne, 2013), if the value is less than 0.05, it reflects an acceptable and perfect fit (see Table 5).

\subsubsection{Mediation analysis}

To test the brand image mediating role, we employed Hair et al. (2016) approach. According to MacKinnon et al. (2002), Z mediates the link between $\mathrm{X}$ and $\mathrm{Y}$ if the direct path between $\mathrm{X}$ to $\mathrm{Z}$ and $\mathrm{Z}$ to $\mathrm{Y}$ is significant. As demonstrated in (Table 5) the direct path from the celebrity endorsement to brand image $(\beta=0.2204, p=0.007)$ and from brand image to green consumer buying behavior $(\beta=0.3625, p=0.001)$ were positive and statistically significant.

If the direct and indirect effects are substantial, there is partial mediation (Matthews, Hair, \& Matthews, 2018). Hence, this study confirmed the partial mediation of brand image between celebrity endorsement and green consumer buying behavior in the cosmetic industry of Pakistan.

Table 5. Path coefficient, hypothesis testing, coefficient of determination $\left(\mathrm{R}^{2}\right)$ and model fit (SRMR)

\begin{tabular}{|c|c|c|c|c|c|c|c|}
\hline \multirow{2}{*}{ Hypothesis } & Relationships & \multirow{2}{*}{$\begin{array}{c}\text { Original } \\
\text { coefficient } \\
(\beta)\end{array}$} & \multicolumn{2}{|c|}{ Standard bootstrap results } & Mean \\
value & Standard & & $p$-value \\
error & $t$-value & $\begin{array}{c}p \text { - } \\
(2- \\
\text { sided })\end{array}$ & pecision \\
\hline H1 & $\begin{array}{l}\text { Celebrity } \\
\text { endorsement } \rightarrow \\
\text { Green consumer } \\
\text { buying behavior }\end{array}$ & 0.220 & 0.221 & 0.081 & 2.710 & 0.007 & Supported \\
\hline H2 & $\begin{array}{l}\text { Promotional } \\
\text { activities } \rightarrow \text { Green }\end{array}$ & 0.127 & 0.124 & 0.060 & 2.103 & 0.035 & Supported \\
\hline
\end{tabular}

Sukkur IBA Journal of Management and Business - SIJMB | Vol 7 No. 1 January - June 2020 @) Sukkur IBA University 
Sikandar Ali et al Antecedents of Green Consumer Behavior the Mediating Role of Brand Image in the Cosmetic Industry

\begin{tabular}{|c|c|c|c|c|c|c|c|}
\hline & $\begin{array}{l}\text { consumer buying } \\
\text { behavior }\end{array}$ & & & & & & \\
\hline H3 & $\begin{array}{l}\text { Packaging of } \\
\text { products } \rightarrow \text { Green } \\
\text { consumer buying } \\
\text { behavior }\end{array}$ & 0.247 & 0.249 & 0.065 & 3.783 & 0.002 & Supported \\
\hline $\mathrm{H} 4$ & $\begin{array}{l}\text { Celebrity } \\
\text { endorsement } \rightarrow \\
\text { Brand image }\end{array}$ & 0.552 & 0.553 & 0.061 & 8.951 & 0.001 & Supported \\
\hline H5 & $\begin{array}{l}\text { Brand image } \rightarrow \\
\text { Green consumer } \\
\text { buying behavior }\end{array}$ & 0.362 & 0.362 & 0.070 & 5.159 & 0.001 & Supported \\
\hline \multicolumn{8}{|c|}{ Indirect effect: } \\
\hline H6 & $\begin{array}{l}\text { Celebrity } \\
\text { endorsement } \rightarrow \\
\text { Brand image } \rightarrow \\
\text { Green consumer } \\
\text { buying behavior }\end{array}$ & 0.200 & 0.200 & 0.043 & 4.693 & 0.001 & Supported \\
\hline \multicolumn{2}{|c|}{ Dependent variable: } & \multicolumn{4}{|c|}{ Coefficient of determination $\left(\mathrm{R}^{2}\right)$} & \multicolumn{2}{|c|}{ SRMR } \\
\hline \multicolumn{2}{|r|}{ Brand image } & \multicolumn{4}{|c|}{0.3046} & & \\
\hline \multicolumn{2}{|c|}{$\begin{array}{c}\text { Green consumer buying } \\
\text { behavior }\end{array}$} & \multicolumn{4}{|c|}{0.6207} & \multicolumn{2}{|c|}{0.0491} \\
\hline
\end{tabular}


Sikandar Ali et al Antecedents of Green Consumer Behavior the Mediating Role of Brand Image in the Cosmetic Industry

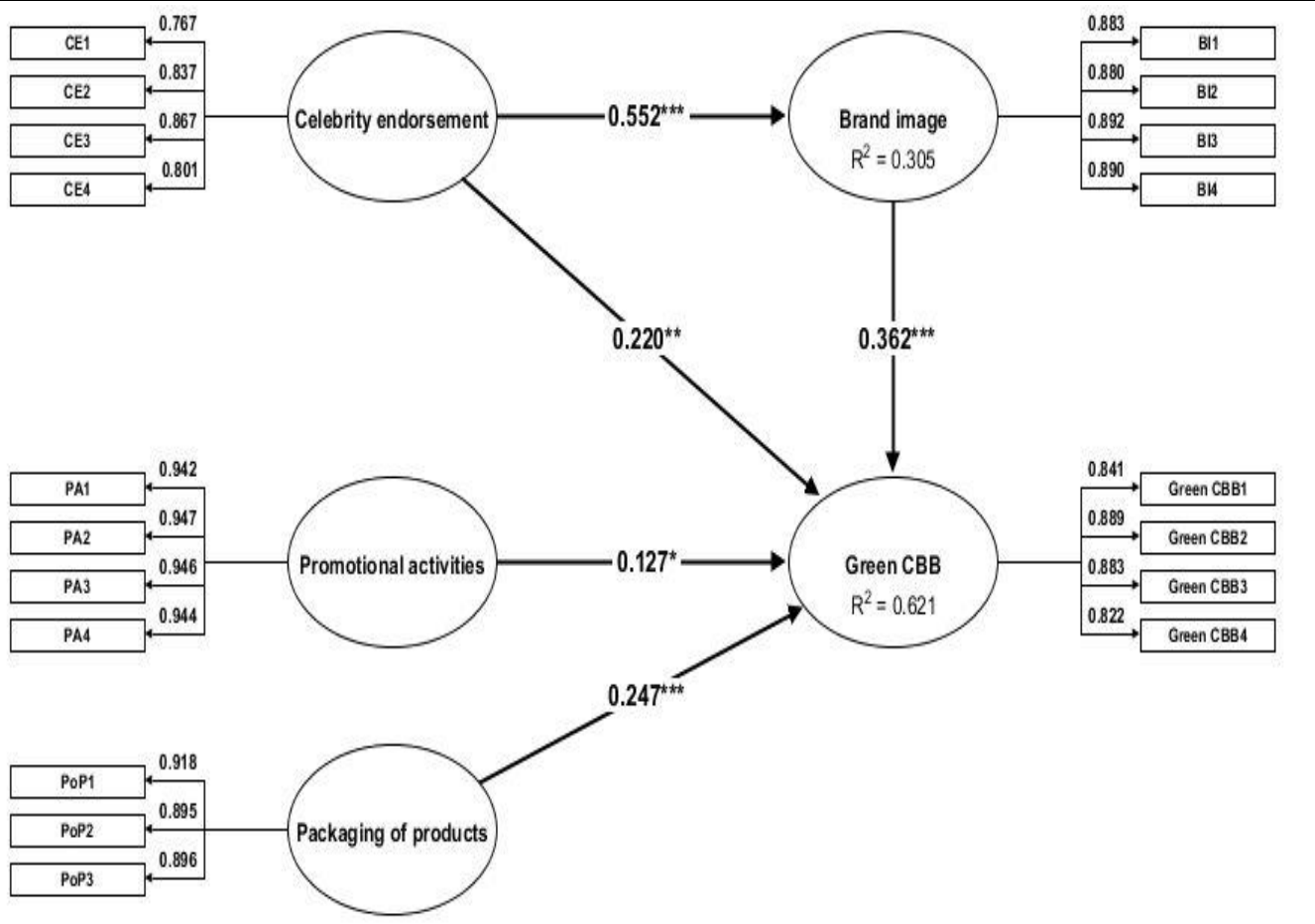

Figure 2. Structural equation modeling.

Our survey shows that celebrity endorsement and green consumer buying behavior have a positive and statistically relationship $(\beta=0.2204, \mathrm{p}=0.0070)$; hence, hypothesis 1 supported. Promotional activities have a positive and statistically significant relationship with green consumer buying behavior $(\beta=0.1268, p=0.0357)$; thus, hypothesis 2 supported. The positive and statistically significant relationship found between the packaging of products and green consumer buying behavior $(\beta=0.2468$, $\mathrm{p}=0.0002$ ); therefore, hypothesis 3 supported. Celebrity endorsement has a positive and statistically significant relationship with a brand image $(\beta=0.5519, p=0.0000)$; hence, hypothesis 4 supported. Brand image has a positive and statistically significant relationship with green consumer buying behavior $(\beta=0.3625, p=0.0000)$, henceforth, hypothesis 5 supported. The brand image significantly mediates a positive relationship between celebrity endorsement and green consumer buying behavior $(\beta=0.2000$, $\mathrm{p}=0.0000)$; thus, indirect hypothesis 6 supported.

\section{Discussion and Conclusion}

Based on the objectives of our paper and to reduce the research gap, we used the theory of planned behavior and developed the conceptual model. Our approved model investigated the important role of promotional activities, brand image, celebrity endorsement, packaging and their effects on green consumer buying behavior. Based

Sukkur IBA Journal of Management and Business - SIJMB | Vol 7 No. 1 January - June 2020 @ Sukkur IBA University 
Sikandar Ali et al Antecedents of Green Consumer Behavior the Mediating Role of Brand Image in the Cosmetic

on the results and findings, all of the hypotheses are confirmed. Our results correlate with Cuomo et al. (2019), which states that celebrity endorsement has positive effects on luxurious brands, purchase intentions, and brand awareness. Our survey shows that celebrity endorsement and green consumer buying behavior have a positive and statistically relationship. This research finding consistent with Chekima et al. (2018), who found positive impacts of celebrity endorsement on consumer purchase decisions through using expertise, attractiveness, and trustworthiness characteristics of celebrity endorsement.

Promotional activities have a positive and statistically significant relationship with green consumer buying behavior. The findings of the study consistent with Codini et al. (2018), who conclude that consumers under a state of promotional activities intend to buy green products.

The positive and statistically significant relationship found between the packaging of products and green consumer buying behavior. This finding of study consistent with the work of Orzan et al. (2018); the author found the positive effects of eco-friendly packaging on consumers' sustainable behavior.

Celebrity endorsement has a positive and statistically significant relationship with a brand image. These findings of the study consistent with work of Ford (2018), who proposed that celebrity endorsement improve the credibility of advertisings, linking of advertisement and also enhance the purchase behavior, brand awareness, and brand image.

Brand image has a positive and statistically significant relationship with green consumer buying behavior. This result of the study consistent with $\mathrm{Ng}$ et al. (2014), who found the significant effects of brand image on green product buying intention.

The brand image significantly mediates a positive relationship between celebrity endorsement and green consumer buying behavior. These findings of the study consistent with Chan et al. (2013); Ramesh et al. (2019), who found positive mediation of brand image between the proposed construct.

This study aims to investigate the relationship between consumers buying behavior and celebrity endorsement while purchasing the cosmetics products in Pakistan, from results it has been concluded that independent variables have a significant relationship with dependent variable green consumers buying behavior, so cosmetic companies/brands should focus on these factors to increase their sales and their shares in the market. As well as the government and environment-friendly organization should motivate public and private firms to promote green consumption of products.

\section{The theoretical and managerial implication 6.1 Theoretical implication}

This study has practical implications of consumer buying behavior and celebrity endorsement. This study explored the relationship of Consumer buying behavior and

Sukkur IBA Journal of Management and Business - SIJMB | Vol 7 No. 1 January - June 2020 C Sukkur IBA University 
Sikandar Ali et al Antecedents of Green Consumer Behavior the Mediating Role of Brand Image in the Cosmetic

celebrity endorsement, while earlier studies focus on customer satisfaction and consumer perception of the brand (Erkmen \& Hancer, 2019) or efficient use of resources (Yue, Long, \& Chen, 2013), and how much consumers are committed towards the brand (Albert \& Merunka, 2013). As celebrity endorsement is the most influential way of marketing in the cosmetic industry and provides better returns despite its importance, there was less attention paid towards its literature work, so this study aims to cover up that literature gap in the new perspective of marketing.

Secondly studied the green consumer Buying behavior, as the consumer behavior is influenced by the celebrity endorsement and consumer wish to buy item promoted by celebrity, as studies focus on the behavior of consumers to purchase green products (Liang et al., 2019; Wang et al., 2017). But the effect of celebrity endorsement on purchasing green products was ignored. Theory of planned behavior used to construct the theoretical framework which helps us to determine the behavioral intentions of the consumer buy green cosmetic products, whereas the study confirms that the subject norms of consumers and attitude influence their intention to buy green products. The theory helped us to understand the whole phenomenon.

\subsection{Managerial implication}

This paper also has implications for the managers, as the competition for sales among companies has increased, and each company wants to have maximum sales, competition among the cosmetic industry is also increasing. So, this study will help managers and advertisement agencies create stimuli for their consumers.

First, managers need to find the most influential celebrity to endorse the product to influence consumer green buying behavior. As a result of this study illustrated the majority of respondents are well educated, frequent buyers, and spend over 3000 a month, and prefer to buy imported products. It directs to managers that their marketing strategies should be targeted to youth and focused more on the quality of products and cumulative advantage it provides to society.

Besides, it also helps practitioners to achieve sustainability and increase the company image; for instance, according to our study, celebrity endorsement for buying environmental-friendly products motivates consumers to buy green cosmetic products as people follow them. Managers can use this result and can advertise their product through celebrities and gain profits. It will increase the image of the company because it is promoting environmental-friendly products, which is positively contributing to climate.

\section{Limitations and future recommendation}

This study has certain limitations that highlight the avenue for future research. The limitations of the study include that we had only 190 respondents. As we considered four universities of Pakistan only, and the model was tested in a single country through

Sukkur IBA Journal of Management and Business - SIJMB | Vol 7 No. 1 January - June 2020 C Sukkur IBA University 
a convenience sampling approach. Therefore, limiting the generalizability of the findings, future studies should employ a cross-cultural approach to investigate the impacts of antecedents used and the mediation of brand image on green consumer buying behavior.

This study focused on females only; this can be extended to males' as well as also studied from different age group's perspectives. We only took females as our sample because females tend to be intrinsically motivated to buy green products (Gilal et al., 2019). The majority of the consumers in the cosmetic industry are females compare to males, so we go with the majority. However, we left room for future researchers to explore the study while taking both female and male into consideration and how gender influences consumer buying behavior because it states that there is a difference in the product design preferences when it comes to gender (Gilal et al., 2018).

There are many other predecessors and influencing factors, using only four-factor (e.g. celebrity endorsement, packaging of the product, promotional activities, and brand image) may be considered a limitation. Hypotheses were developed using developing country data; therefore, the results may not be generalizable to developed countries.

In future researchers can also add the age demographics into the research to explore the effect of celebrity endorsement on different age groups of consumers. As well as gender can moderate the link between antecedents and green consumer buying behavior. Whereas because of the limitation of time, only a few variables are studied, other variables can also be considered to study the behavior of green consumers. This study can be extended with the mediation of brand image and moderation of gender. Also, this study can be used in other developing countries and industries.

\section{References}

Adam, M., \& Hussain, N. (2017). Impact of celebrity endorsement on consumers buying behavior. British Journal of Marketing Studies, 5(3), 79-121.

Adi, P. H. (2012). Antecendents of consumers perception and its Influence towards purchase intention on cosmetics product. Jurnal Ekonomi dan Keuangan.

Albert, N., \& Merunka, D. (2013). The role of brand love in consumer- brand relationships. Journal of consumer marketing, 30(3), 258-266.

Ali, S. (2017). The antecedents of consumer intention to purchase halal cosmetic products in Pakistan: using behavioral reasoning theory. Universiti Utara Malaysia,

Amatulli, C., De Angelis, M., Peluso, A. M., Soscia, I., \& Guido, G. (2019). The effect of negative message framing on green consumption: An investigation of the role of shame. Journal of Business Ethics, 157(4), 1111-1132.

Amberg, N., \& Fogarassy, C. (2019). Green Consumer Behavior in the Cosmetics Market. Resources, 8(3), 137.

Ateke, B. W., Onwujiariri, J. C., \& Nnennanya, D. A. (2015). The relationship between celebrity endorsement and brand image in the fastfood industry in Port Harcourt, Nigeria. European Journal of Business and Management, 7(27), 177-186.

Bagozzi, R. P., \& Yi, Y. (1988). On the evaluation of structural equation models. Journal of the academy of marketing science, 16(1), 74-94.

Sukkur IBA Journal of Management and Business - SIJMB | Vol 7 No. 1 January - June 2020 @ Sukkur IBA University 
Sikandar Ali et al Antecedents of Green Consumer Behavior the Mediating Role of Brand Image in the Cosmetic

Barclay, D., Higgins, C., \& Thompson, R. (1995). The partial least squares (PLS) approach to casual modeling: personal computer adoption and use as an Illustration. Technology Studies, 2(2), 285-309.

Byrne, A., Whitehead, M., \& Breen, S. (2003). The naked truth of celebrity endorsement. British Food Journal.

Byrne, B. M. (2013). Structural equation modeling with LISREL, PRELIS, and SIMPLIS: Basic concepts, applications, and programming: Psychology Press.

Chan, K., Ng, Y. L., \& Luk, E. K. (2013). Impact of celebrity endorsement in advertising on brand image among Chinese adolescents. Young Consumers.

Chekima, F. Z., Wafa, S. A. W. S. K., \& Sulong, R. S. (2018). The Impact of Celebrity Credibility on Purchase Intention of Cosmetic Products: The Moderating Role of Ethnocentrism. Asian Journal of Economics, Business and Accounting, 1-10.

Chen, Y.-S., Huang, A.-F., Wang, T.-Y., \& Chen, Y.-R. (2020). Greenwash and green purchase behaviour: the mediation of green brand image and green brand loyalty. Total Quality Management \& Business Excellence, 31(1-2), 194-209.

Codini, A. P., Miniero, G., \& Bonera, M. (2018). Why not promote promotion for green consumption? European Business Review.

Cohen, J. (1998). Statistical Power Analysis for the Behavioural Sciences, xxi. In: Hillsdale, NJ: L Erlbaum associates.

Cuomo, M. T., Foroudi , P., Tortora, D., Hussain, S., \& Melewar, T. C. (2019). Celebrity Endorsement and the Attitude Towards Luxury Brands for Sustainable Consumption. Sustainbility, 2-21.

de Medeiros, J. F., \& Ribeiro, J. L. D. (2017). Environmentally sustainable innovation: Expected attributes in the purchase of green products. Journal of cleaner production, 142, 240-248.

Durrani, B. A., Godil, D. I., Baig, M. U., \& Sajid, S. (2015). Impact of brand image on buying behaviour among teenagers. European Scientific Journal, 11(5).

Erkmen, E., \& Hancer, M. (2019). Building brand relationship for restaurants. International Journal of Contemporary Hospitality Management, 31(3), 1469-1487

Fassott, G., Henseler, J., \& Coelho, P. S. (2016). Testing moderating effects in PLS path models with composite variables. Industrial Management \& Data Systems.

Ford, J. B. (2018). What do we know about celebrity endorsement in advertising? In: Journal of Advertising Research.

Fornell, C., \& Larcker, D. F. (1981). Evaluating structural equation models with unobservable variables and measurement error. Journal of marketing research, 18(1), 39-50.

Gauns, K. K., Pillai, S. K. B., Kamat, K., Chen, R. F., \& Chang, L.-C. (2018). Impact of celebrity endorsement on consumer buying behaviour in the state of Goa. IIM Kozhikode Society \& Management Review, 7(1), 45-58.

Ghosh, B. K. (2016). Impact of packaging on consumers' buying behaviour: a case study of mother dairy, Kolkata. Parikalpana: KIIT Journal of Management, 12(2), 27-34.

Gilal, F. G., Chandani, K., Gilal, G. R., Gilal, N. G., Channa, N. A., \& Gilal, W. G. (2019). Towards a new model for green consumer behaviour: A self- determination theory perspective. Sustainable Development

Gilal, f. g., Channa, N. A., Gilal, N. G., Gilal, R. G., Gong , Z., \& Zhang, N. (2020). Corporate social responsibility and brand passion among consumers: Theory and evidence. Corporate Social Responsibility and environmental management.

Sukkur IBA Journal of Management and Business - SIJMB | Vol 7 No. 1 January - June 2020 @ Sukkur IBA University 
Sikandar Ali et al Antecedents of Green Consumer Behavior the Mediating Role of Brand Image in the Cosmetic

Gilal, F. G., Zhang, J., Gilal, N. G., \& Gilal, R. G. (2018). Integrating self-determined needs into the relationship among product design, willingness-to-pay a premium, and word-ofmouth: a cross-cultural gender-specific study. Psychology research and behavior management, 11, 227-241.

Gill, M. S., \& Dawra, J. (2010). Evaluating Aaker's sources of brand equity and the mediating role of brand image. Journal of targeting, measurement and analysis for marketing, 18(34), 189-198.

Goodhue, D. L., Lewis, W., \& Thompson, R. (2012). Does PLS have advantages for small sample size or non-normal data? MIS quarterly, 981-1001.

Groeneveld, S., Tummers, L., Bronkhorst, B., Ashikali, T., \& Van Thiel, S. (2015). Quantitative methods in public administration: Their use and development through time. International Public Management Journal, 18(1), 61-86.

Hair, J. F., Sarstedt, M., Pieper, T. M., \& Ringle, C. M. (2012). The use of partial least squares structural equation modeling in strategic management research: a review of past practices and recommendations for future applications. Long range planning, 45(5-6), 320-340.

Hair Jr, J. F., Hult, G. T. M., Ringle, C., \& Sarstedt, M. (2016). A primer on partial least squares structural equation modeling (PLS-SEM): Sage publications.

Hair Jr, J. F., Sarstedt, M., Ringle, C. M., \& Gudergan, S. P. (2017). Advanced issues in partial least squares structural equation modeling: saGe publications.

Henseler, J. (2017). Adanco 2.0. 1. User Manual. Kleve: Composite Modeling GmbH \& Co.

Henseler, J. (2018). Partial least squares path modeling: Quo vadis? Quality \& Quantity, 52(1), $1-8$.

Henseler, J., \& Dijkstra, T. (2018). ADANCO 2.1, composite modeling, Kleve. In.

Henseler, J., Ringle, C. M., \& Sinkovics, R. R. (2009). The use of partial least squares path modeling in international marketing. In New challenges to international marketing (pp. 277-319): Emerald Group Publishing Limited.

Hu, L. t., \& Bentler, P. M. (1999). Cutoff criteria for fit indexes in covariance structure analysis: Conventional criteria versus new alternatives. Structural equation modeling: a multidisciplinary journal, 6(1), 1-55.

Jamil, K., Ali, M. A., \& Iqbal, A. (2017). Exploring Brand Awareness, Customer Loyalty and Perceived Quality: how they ensure Profitability and generate Purchase Intention: A study on cosmetic industry of Pakistan. Journal of Social and Development Sciences, 8(3), 4045.

Jin, N., Line, N. D., \& Ann, S. H. (2015). The full-service dining experience: An assessment of the generation-specific determinants of customer loyalty. Journal of Foodservice Business Research, 18(4), 307-327.

Jin, S. V. (2018). "Celebrity 2.0 and beyond!" Effects of Facebook profile sources on social networking advertising. Computers in Human Behavior, 79, 154-168.

Kaufmann, H. R., \& Panni, M. F. A. K. (2017). Socio-economic Perspectives on Consumer Engagement and Buying Behavior: IGI Global.

Khare, A. (2015). Antecedents to green buying behaviour: a study on consumers in an emerging economy. Marketing Intelligence \& Planning.

Kumar, R., \& Tripathi, V. (2019). Green Advertising: Examining the Role of Celebrity's Credibility Using SEM Approach. Global Business Review, 0972150919862660.

Liang, D., Hou, C., Jo, M.-S., \& Sarigöllü, E. (2019). Pollution avoidance and green purchase: The role of moral emotions. Journal of cleaner production, 210, 1301-1310.

Sukkur IBA Journal of Management and Business - SIJMB | Vol 7 No. 1 January - June 2020 @ Sukkur IBA University 
Sikandar Ali et al Antecedents of Green Consumer Behavior the Mediating Role of Brand Image in the Cosmetic

Lin, C.-Y. (2015). Conceptualizing and measuring consumer perceptions of retailer innovativeness in Taiwan. Journal of Retailing and Consumer Services, 24, 33-41.

Lin, Y., Yang, S., Hanifah, H., \& Iqbal, Q. (2018). An exploratory study of consumer attitudes toward green cosmetics in the UK market. Administrative Sciences, 8(4), 71.

Liobikienė, G., Grincevičienè, Š., \& Bernatonienè, J. (2017). Environmentally friendly behaviour and green purchase in Austria and Lithuania. Journal of cleaner production, 142, 3789-3797.

MacKinnon, D. P., Lockwood, C. M., Hoffman, J. M., West, S. G., \& Sheets, V. (2002). A comparison of methods to test mediation and other intervening variable effects. Psychological methods, 7(1), 83.

Matthews, L., Hair, J., \& Matthews, R. (2018). Pls-Sem: The Holy Grail for Advanced Analysis. Marketing Management Journal, 28(1).

Mishra, P., Jain, T., \& Motiani, M. (2017). Have green, pay more: an empirical investigation of consumer's attitude towards green packaging in an emerging economy. In Essays on Sustainability and Management (pp. 125-150): Springer.

Mullin, R. (2018). Promotional marketing: Routledge.

Nagar, K., \& Rana, S. (2015). Examining linkages between brand image and purchase intention of green products: The moderating role of perceived benefits. FIIB Business Review, 4(2), 63-72.

Ng, P. F., Butt, M. M., Khong, K. W., \& Ong, F. S. (2014). Antecedents of green brand equity: an integrated approach. Journal of Business Ethics, 121(2), 203-215.

Nunnally, J. (1978). Psychometric methods. In: New York: McGraw-Hill.

Orzan, G., Cruceru, A. F., Bălăceanu, C. T., \& Chivu, R.-G. (2018). Consumers' Behavior Concerning Sustainable Packaging: An Exploratory Study on Romanian Consumers. Sustainability, 10(6), 1787.

Prakash, G., \& Pathak, P. (2017). Intention to buy eco-friendly packaged products among young consumers of India: A study on developing nation. Journal of cleaner production, 141, 385-393.

Ramesh, K., Saha, R., Goswami, S., \& Dahiya, R. (2019). Consumer's response to CSR activities: Mediating role of brand image and brand attitude. Corporate Social Responsibility and Environmental Management, 26(2), 377-387.

Roldán, J. L., \& Sánchez-Franco, M. J. (2012). Variance-based structural equation modeling: Guidelines for using partial least squares in information systems research. In Research methodologies, innovations and philosophies in software systems engineering and information systems (pp. 193-221): IGI Global.

Royne, M. B., Thieme, J., Levy, M., Oakley, J., \& Alderson, L. (2016). From thinking green to buying green: Consumer motivation makes the difference. Journal of Business Strategy.

Salem, M. Z. (2018). Effects of perfume packaging on Basque female consumers purchase decision in Spain. Management Decision.

Salganik, M. J., \& Heckathorn, D. D. (2004). Sampling and estimation in hidden populations using respondent- driven sampling. Sociological methodology, 34(1), 193-240.

Shallu, M., \& Gupta, S. (2013). Impact of promotional activities on consumer buying behavior: a study of cosmetic industry. International Journal of Commerce, Business and Management, 2(6), 379-385.

Silayoi, P., \& Speece, M. (2004). Packaging and purchase decisions: An exploratory study on the impact of involvement level and time pressure. British food journal, 106(8), 607-628.

Sukkur IBA Journal of Management and Business - SIJMB | Vol 7 No. 1 January - June 2020 @ Sukkur IBA University 
Sikandar Ali et al Antecedents of Green Consumer Behavior the Mediating Role of Brand Image in the Cosmetic

Simmonds, G., \& Spence, C. (2017). Thinking inside the box: How seeing products on, or through, the packaging influences consumer perceptions and purchase behaviour. Food Quality and Preference, 62, 340-351.

Singhal, A., \& Malik, G. (2018). The attitude and purchasing of female consumers towards green marketing related to cosmetic industry. Journal of Science and Technology Policy Management.

Sohail, S. (2016). Green Marketing and its impact on consumer based brand equity. Paper presented at the Proceedings of the international conference on innovation and entrepreneurship.

Spry, A., Pappu, R., \& Cornwell, T. B. (2011). Celebrity endorsement, brand credibility and brand equity. European journal of marketing.

Suki, N. M. (2016). Green product purchase intention: impact of green brands, attitude, and knowledge. British Food Journal.

Sun, Y., Liu, N., \& Zhao, M. (2019). Factors and mechanisms affecting green consumption in China: A multilevel analysis. Journal of cleaner production, 209, 481-493.

Tariq, M., Abbas, T., Abrar, M., \& Iqbal, A. (2017). EWOM and brand awareness impact on consumer purchase intention: Mediating role of brand image. Pakistan Administrative Review, 1(1), 84-102.

Taufique, K. M. R., \& Vaithianathan, S. (2018). A fresh look at understanding Green consumer behavior among young urban Indian consumers through the lens of Theory of Planned Behavior. Journal of cleaner production, 183, 46-55.

Voorhees, C. M., Brady, M. K., Calantone, R., \& Ramirez, E. (2016). Discriminant validity testing in marketing: an analysis, causes for concern, and proposed remedies. Journal of the academy of marketing science, 44(1), 119-134.

Wang, M. J., \& Uslay, C. (2018). Jumei: China's top online cosmetics retailer and the quest to become the top E-commerce hub for women. Emerald Emerging Markets Case Studies.

Wang, Z., Wang, X., \& Guo, D. (2017). Policy implications of the purchasing intentions towards energy-efficient appliances among China's urban residents: Do subsidies work? Energy Policy, 102, 430-439.

Weiss, N. A., \& Weiss, C. A. (2012). Introductory Statistics: Pearson Education.

Wong, K. K.-K. (2013). Partial least squares structural equation modeling (PLS-SEM) techniques using SmartPLS. Marketing Bulletin, 24(1), 1-32.

Yousaf, U., Zulfiqar, R., Aslam, M., \& Altaf, M. (2012). Studying brand loyalty in the cosmetics industry. LogForum, 8(4).

Yue, T., Long, R., \& Chen, H. (2013). Factors influencing energy-saving behavior of urban households in Jiangsu Province. Energy Policy, 62, 665-675.

Zhang, Y., Xiao, S., \& Zhou, G. (2019). User continuance of a green behavior mobile application in China: An empirical study of Ant Forest. Journal of Cleaner Production 